\title{
Graduates of the Bachelor of History: Occupational Market, Demands and Level of Satisfaction of Vocational Training
}

\author{
Ana Berónica Palacios Gámaz ${ }^{{ }^{*}}$, María Guadalupe López Morales ${ }^{2}$, Jorge Luis Fidel Torres \\ Rojas $^{3}$, Olga Lidia Lopes Gonzales ${ }^{4}$, María del Rocío Pérez Farrera ${ }^{5}$ \\ ${ }^{1}$ PhD in Scientific-Social Studies. Professor at the Faculty of Social Sciences of the Autonomous University of \\ Chiapas, Mexico. \\ ${ }^{2}$ PhD in Human Rights. Professor at the Faculty of Law of the Autonomous University of Chiapas. \\ ${ }^{3}$ PhD inPedagogy. Professor at the Faculty of Social Sciences of the Autonomous University of Chiapas, \\ Mexico. \\ ${ }^{4}$ Master of Science in the Health and Development Line. Professor at the Faculty of Social Sciencesof the \\ Autonomous University of Chiapas, Mexico.
}

${ }^{5}$ Master in Administration. Professor at the Faculty of Social Sciences of the Autonomous University of Chiapas, Mexico.

*Corresponding Author: Ana Berónica Palacios Gámaz, PhD in Scientific-Social Studies. Professor at the Faculty of Social Sciences of the Autonomous University of Chiapas, Mexico.

\begin{abstract}
This work addresses the study of graduates of the Bachelor of History of the Faculty of Social Sciences, of the Autonomous University of Chiapas (UNACH), Mexico, through the analysis of professional performance and the degree of satisfaction with their professional training received, that allows generating strategies that provide feedback on the study program and improve the processes of its planning, updating and consolidation. Higher education institutions are currently facing new challenges, among which the social impact generated by professionals in the labor field stands out. Therefore, it is necessary for institutions to create strategies to analyze this process and identify new training demands that respond to society. Thus, graduate studies contribute to improving the quality of education, in order to contribute to solving problems.The study was carried out in the period 2019-2020, through a quantitative methodological strategy, based on the proposal made in this regard by the National Association of Universities and Institutions of Higher Education in Mexico.The results show a low degree of graduates of the program, a high rate of employment, but a low proportion of employment at the professional level and low certainty in the employment contract. They highlight the positive evaluations of their professional training and propose improving aspects of the development of capacities to choose jobs in different economic sectors.
\end{abstract}

Key terms: Graduates, History, occupational market, professional training.

\section{INTRODUCTION}

Societies today are characterized by the sense of dilution of certainties. The solid institutions of yesteryear that organize social practices are weakened and in constant flux.The transformations have been complex in the multiple dimensions of social life: economic, political, cultural, social and environmental. In this process of globalization, the nation state faces a dismantling, especially due to the diversification of the functions of space in the face of global economic dynamics (Beck, 2008). , another where companies make their tax declaration and another where they reside. This kind of power is exercised by transnational actors, which makes it possible to outline an economic system without work and without taxes, produced by a decapitalized State, with difficulties in financing the wellbeing of its population (Palacios, 2013).According to Granados (2013) we are moving towards the flexibility and high competitiveness of the world of work: "This is the product of the neoliberal state which we could call dismantler - that operates through deregulation, flexibility and thinning" (p.11).Which generates a serious situation of unemployment and precarious employment worldwide.

However, since it is not possible to consider "homogeneous" characteristics of the labor market for all countries, due to the great differences and unequal regional contexts, it is pertinent to recognize 
constant factors in the "world of employment", as universal constants (González, 2000), such as the following:

- Massive reconversion of broad economic sectors to meet the acceleration of technological changes and work organization.

- The implications of new technologies on the relevance of jobs and their transformations in the way of exercising them.

- Greater job creation in the tertiary sector and the search for excellence in the sector.

- Increasing relevance of independent work or self-employment in the transformation of economic structures.

- Global trend towards privatization of the economy and reduction of State intervention, which affects the characteristics of job security.

- Importance of sustainable economic development will affect employment and consumption.

- Tendency to unemployment or long-term unemployment, derived from the aforementioned factors and insufficient training to adapt to the evolution of the economy (technological changes, in the organization of work and in the labor market).

González (2000) considers that the nature of the labor market is dynamic, changing, so that jobs and qualifications are constantly being transformed, before which "The ability to adapt, based on flexible training, becomes the main insurance against unemployment for the majority of people "(p.1).

The relationship between education and work is long-standing, since it refers to the need for human beings to work to earn a living; But this relationship is not only involved in the economic dimension, but also in politics, because education and work are constituent elements of every democratic society; Likewise, educational level and qualification are factors of access to employment and job promotion.Among the main competencies that the contemporary world of work requires from workers, they refer to the ability to take initiatives, follow abstract reasoning, self-learning and work in a group or team. (González, 2000).

\section{Professionalists AND THE LABOR MARKeT}

According to data from CEPAL (Palacios, 2013), the gaps in unemployment rates have deepened in recent years. It is important to mention the decrease in the participation of young men and women in employment; It is not only about economic conditions, but also about the relevant way under which socio-cultural aspects such as norms, values and institutional factors of each context, exacerbate the situation of young women in some regions of the world.

In Mexico, according to recent data from the National Survey of Occupation and Employment, of the National Institute of Statistics and Geography (INEGI) (2020), the employed population in the country is $55,352,304$ inhabitants, of which $11.88 \%$ are inserted in the primary sector, $24.93 \%$ in the secondary sector and $62.59 \%$ in the tertiary sector.

Regarding the population with higher and higher secondary level studies, it represents $38.81 \%$ of the employed population at the national level and in Chiapas, it represents $30.99 \%$ of the employed population at the state level.

At the national level, of the employed population with higher and higher secondary level studies (38.81\%) is distributed by economic sector as follows: $3.67 \%$ is inserted in the primary sector, $20.41 \%$ in the secondary sector and in the tertiary sector $75.91 \%$.

In the case of Chiapas, the employed population with higher and higher education $(30.99 \%)$ is distributed by economic sector as follows: $10.3 \%$ is inserted in the primary sector, $13.11 \%$ in the secondary sector and in the tertiary sector $76.58 \%$.

Table No.1. Employed population with upper secondary and higher education, 2020

\begin{tabular}{|l|l|l|}
\hline Economic sector & National Level Mexico & Estate Level Chiapas \\
\hline Proportion of the employed EAP & $38.81 \%$ & $30.99 \%$ \\
\hline Primary sector & $3.67 \%$ & $10.3 \%$ \\
\hline
\end{tabular}


Graduates of the Bachelor of History: Occupational Market, Demands and Level of Satisfaction of Vocational Training

\begin{tabular}{|l|l|l|}
\hline Secondary sector & $20.41 \%$ & $13.11 \%$ \\
\hline Third sector & $75.91 \%$ & $76.58 \%$ \\
\hline
\end{tabular}

Source: National Survey of Occupation and Employment, 2020, INEGI.

A problem in the question of professionals and employment lies in the overqualification that can cause many professionals to tend to occupy less paid jobs in relation to their academic and technical capacities.According to Suárez (2014), in Mexico, the highest unemployment rates are found in the population with higher educational levels, a problem exacerbated by the fact that approximately half of the graduates of higher education institutions They work in jobs not related to their professional career and each year thousands of graduates seek to integrate into the labor market.

Granados (2013) tells us that the certainty that the possession of a professional title gave for insertion in the labor market and social mobility, was devalued in the last three decades and currently professionals can only choose to "perform one or more jobs under highly flexible conditions, without benefits, social security and job stability, inserting into the informal market or joining the ranks of legal unemployment"(p.12).

The labor market demands more and more competitive professionals, which places higher education institutions in a context of high pressure in contexts of instability, flexibility, financing problems, high demand and bureaucratization.

\section{Studies of Graduates in MeXico}

Contemporary societies today require the permanent evaluation and monitoring of the fulfillment of the functions and quality service of their various institutions, as is the case of the universities, responsible for the training of professionals that allow progress towards sustainable and sustainable societies, in a local-global dynamic, which places higher education institutions in a highly competitive process, faced with a demanding, restrictive and precarious labor market, and a society with diverse and complex problems that require capable and ethical professionals. (Rosales et al, 2017).

In this context, universities must take as principles, according to the Regional Conference on Higher Education for Latin America and the Caribbean, sponsored by the United Nations Organization for Education, Science and Culture (Organization of Ibero-American States for Education, Science and Culture, 2008), that higher education constitutes a public and social good, it is a human, universal right and a duty of the State. The primary value of higher education is linked to the construction of more prosperous, just and supportive societies and with a model of sustainable integral human development.

Higher education institutions are in need of the search for educational excellence, the responsibility to innovate permanently, implement new teaching-learning methods and optimize their resources, as well as the design of tools that allow systematic monitoring and compliance with the quality standards in the educational institution (especially of the accrediting bodies of the education programs), for which they require strategies of continuous and systematic evaluation of the institution, selfevaluation and feedback.

A relevant aspect in the processes of search and / or consolidation of the quality and relevance of higher-level educational programs is the institutional feedback provided by the studies of graduates, which allow us to know the opinions of graduates on the quality of their training professional, the relevance of this in their work performance and the suggestions for updating the study programs in the face of the demands of the labor market and the social environment they face (Aldana et al, 2008).

At the international level, the trend of the importance of evaluating university activities is strengthened, which refers to institutional accountability both to society and to government entities, in which graduate studies constitute a vital aspect. importance (Red Gradua2 and Columbus Association, 2006; cited by Aldana et al, 2008).

In Mexico, the National Association of Universities and Institutions of Higher Education (ANUIES, 1998) states that graduate studies allow, among other aspects:

- Know the impact that the university educational offer has on the labor market.

- Establish the quality of teaching at the university.

International Journal of Humanities Social Sciences and Education (IJHSSE) 
- Know the professional location of the graduates.

- Analyze the social impact of schools and faculties on the labor market.

- Have information that supports decision-making to adapt the university educational offer to the existing demand.

Despite the relevance of having the opinions of graduates as fundamental inputs for curriculum updating, self-evaluation and high-quality accreditation at the higher level, the institutions generally lack support from the State, they do not have sufficient normative and conceptual support, either. There are rigorous criteria for evaluation, to which is added the demotivation of graduates to answer the surveys (Lopera, 2005).

Societies framed in a global-local dynamic are faced with constant technological innovations, social changes and a trend towards labor flexibility expressed in labor relations, the use of technology and work organization, which has implied that international educational policy emphasize the linkage of universities with market requirements and demand an increase in the educational quality offered in higher-level institutions, through a flexible curriculum and training by competencies (Declaration of Bologna and World Declaration on Education Superior in the 21st century).In this sense, universities would have an economic function and not only social, cultural and pedagogical, since they are expected to provide professionals required by the changing labor market, influencing economic growth and social welfare (Ayala, 2009; UAEM , 2009; Guzmán et al, 2008; Escalona and Fernández, 2007; Fresan, 1998).

Higher-level educational institutions in Latin America in recent years have carried out professional training under a market perspective, related to the growth, development and competitiveness of the countries. According to Jiménez (2017), there is an almost determining implication of the market in the pedagogical orientation of universities:

In the globalized context in which Latin American universities are framed, the market vision has been decisive in establishing the ideal of quality [...] In this sense, the practical consequences resulting from professional training are usually used as an indicator of quality. (Jiménez, 2017, p.3).

The link between higher education and the needs of the labor market has been mainly sustained through Schultz's Theory of Human Capital (cited by Escalona and Fernández, 2007, p.116), for whom "the worker had in his power a capital, which was the decision to train to perform a specific activity, to do it with better quality, thus increasing productivity and obtaining, therefore, a better income.For this reason, the worker is the owner of the human capital and the subject of investment since he or the company invests in its preparation, which would yield interest ". Hence, it establishes the relationship between training of human resources with quality productivity.

The quality of higher education institutions considers the development of continuous and systematic evaluation processes that allow them to innovate, discover, design and implement new teachinglearning methods, generation of new knowledge, optimization of resources, among other aspects already which the graduate follow-up studies contribute, which allow knowing the professional performance of the graduates from their own opinions and also on the quality of the education received, the demands of the labor market and the social environment in which it is situated.

The educational quality linked to professional training and employment has been established in different investigations, such as graduate studies, a relevant tool to enrich educational quality(Selfassessment, accreditation through academic peers, etc. have also been considered).

The studies of graduates carried out in Mexico, according to Ibarrola (1988, cited by Escalona and Fernández, 2007, p.117), show:

- The intrinsic relationship between schooling-occupation-income and explains income inequalities; as well as the questions about it.

- The high correlation between social conditions of existence and degree of education.

- The gradual rise in the average level of schooling of those who hold high positions in companies.

- The general restriction in the employment market and the growth of open unemployment. 
- The general bias in the employment market and the growth of open unemployment.

- The bias that the distribution of employment has taken towards the sectors of the population with higher education.

- The unequal demand for schooling according to the employment sector under analysis.

Among the main contributions of recent research on graduates and carried out in the area of Social Sciences in Mexico (Ayala, 2009; Sandoval, 2009; UAEM, 2009; Guzmán et al, 2008; Escalona and Fernández, 2007), we can mention the generation of knowledge about the characteristics of the professionals' employment, the activities they carry out, the knowledge and skills that they require, their performance levels, occupational mobility, salary levels and their repercussions on professional and / or academic expectations; likewise, they allow knowing the demands of employers, identifying the strengths and weaknesses of the study plans, their relevance and efficiency; anticipate changes to arise in the professional field, design professional profiles in accordance with their field of work, and provide elements that complement institutional planning based on the opinion of graduates based on their professional life experiences.

\section{INVESTIGATION METHOD}

The study of graduates of the Bachelor of History of the Faculty of Social Sciences of the UNACH, was carried out through a quantitative methodology and had an exploratory and descriptive scope.In this regard, the methodological proposal of ANUIES (1998) was taken as a basis, which was adapted to the context of the object of study. A non-experimental research design of a transectional type was developed.

The graduates of the current study plan, which dates from 2010, and refer to the generations from 2014 to 2019 were considered as participating subjects. In this regard, the total of graduates the generations of the Bachelor of History mentioned above, was 100, corresponding to 12 generational cohorts from 2014 to 2019 (UNACHa, 2020). The delimitation of the sample was initially proposed as probabilistic, however, it was not possible to locate the graduates delimited with the initial strategy, since they are living in different municipalities of the state of Chiapas and there is no institutional data from its location; In this way, the Snowball Technique was used, which allowed locating a total of 36 graduates, who agreed to participate in the research; This is equivalent to a sample of $36 \%$ of graduates of the generations from 2014 to 2019. Of those surveyed, $61 \%$ are men and $39 \%$ are women.

Obtaining the information from the graduates was carried out through a survey, based on the ANUIES proposal, with adjustments to the particular study program. The questionnaire was made up of open and closed questions, it included ten analysis variables:

1) General data and family history

2) Previous school trajectory

3) Career and location in the labor market

4) Satisfaction with their professional performance

5) Demands in the professional performance of the current job

6) Opinion of the graduates on the training received

7) Graduates' recommendation to improve the professional training profile

8) Opinion on teachers

9) Opinion on the academic organization and services, and

10) Opinion of the graduates about the institution and the degree studied.

For the analysis of the variables of this study, the statistical package IBM Statistical Package for the Social Sciences (SPSS) version 21 was processed. As well as Excel.

\section{ReSUlts}

The Autonomous University of Chiapas took office on April 17, 1975 and nineteen years later, in 1994, the Bachelor of History was created at the Faculty of Social Sciences, located in the city of San 
Cristóbal de Las Casas in the state of Chiapas. ; Federal entity located in the southeast of Mexico and characterized by its great social inequality, high marginalization and the largest population in poverty in the country.

The current study plan for this degree dates from 2010, has the face-to-face modality, is a semester plan with a duration of eight semesters and consists of 234 credits. The mission of this educational program is to train professional historians who are competitive in the field of research, teaching and preservation of cultural heritage, with a sense of social responsibility, community service and respect for cultural diversity. (UNACHb, 2020).

According to the study plan of the Degree in History, the graduate of this degree has the necessary knowledge about History in general to develop activities inherent to the historical discipline, being able to venture into different fields related to the historical task such as research, teaching, dissemination and conservation of cultural heritage. (UNACHb, 2020). The graduates of this study plan, from 2014 to 2019 , add up to a total of 100, of which $35 \%$ are graduates (51\% are women and $49 \%$ are men): of the graduates in 2014, the $40 \%$; of the graduates in $2015,41 \%$; of the graduates in $2016,75 \%$; of the graduates in $2017,7 \%$; of the graduates in $2018,21 \%$; of the graduates in 2019 , there are no graduates. (UNACHa, 2020).

\section{General data of the graduates}

The sex of the graduates (as) surveyed of the BA in History is $61 \%$ men and $39 \%$ women. The maximum age of these (as) is 32 years old and the minimum is 21 years old.

Regarding the place of origin of the graduates, according to the information provided, it can be mentioned that the majority come from different municipalities in the state of Chiapas, in descending order: San Cristóbal de Las Casas (27\%), Tuxtla Gutiérrez (9\%), Tapachula (6\%), Venustiano Carranza (6\%), Chiapa de Corzo (6\%), Villaflores (6\%), La Concordia (6\%), Villa Corzo 3\%), Palenque (3\%), Motozintla de Mendoza (3\%), Bochil (3\%), Yajalón (3\%), Tila (3\%), Huixtán (3\%) and Oxchuc (3\%); Likewise, there are graduates from entities such as Veracruz and Oaxaca, and from another country such as Spain.

Regarding the marital status of the graduates, $85 \%$ declared to be single, $9 \%$ are married, $3 \%$ are divorced and 3\% did not answer the question.

Among the languages spoken by the graduates, according to the data obtained, the majority, $76 \%$, mentioned that they speak only Spanish; approximately one fifth, $18 \%$, speak Spanish and an indigenous language (Tseltal, Tsotsil, Chol, Zoque and Zapotec) and a minimal part, 6\%, speak Spanish and a foreign language.

\section{Choice of institution and career}

For the majority of the graduates of the Bachelor in History, $76 \%$, the Autonomous University of Chiapas was the first option as an educational institution to carry out their professional studies. Likewise, for the majority, 64\%, of the graduates, the Bachelor of History was their first option for professional studies.It stands out that for more than a third of the graduates, $36 \%$, their first option for professional studies was not the BA in History and within the careers thought as the first option were: Pedagogy, Music, Gastronomy, Social Anthropology, Economics, Sociology, Information and Communication Technologies, Literature and Administration, among others.

Among the main reasons or reasons that the graduates surveyed indicated to choose the educational institution where they completed their undergraduate studies, according to the information obtained, a third of the graduates responded that they chose UNACH for its prestige and also because only in this institution was offered the career he wanted, respectively; likewise, $15 \%$ indicated that they chose this institution because it was close to their home and because of the cost of school registration, respectively; to a lesser extent, they responded that their institutional choice was based on the advice of counselors, family and friends, among other aspects.

With regard to the most relevant motives or reasons that the graduates surveyed indicated why they chose to study the Bachelor of History, it stands out that the highest proportion, $42 \%$, mentioned that it was due to vocation and personal abilities; Likewise, for approximately a quarter of respondents, $24 \%$, it was because of the study plan it offered; followed by the prestige of the career, the ease of entering the career and by family tradition. 


\section{Continuity of training}

Regarding the continuation of the training of the graduates surveyed after graduation, $63 \%$ indicated that they continued with other types of studies: $25 \%$ opted for short courses, $22 \%$ for a diploma and $16 \%$ for postgraduate studies. Just over a third of the graduates, $31 \%$, did not continue with postgraduate studies. $6 \%$ did not respond.

\section{Location in the labor market}

Currently, the majority of graduates reported that they have a job, this is equivalent to $79 \%$. About a fifth, $18 \%$, are unemployed and the rest did not answer the question.

Regarding the position held by graduates in the current job, it is worth noting that approximately a quarter of these, $23 \%$, are professional employees; followed by $15 \%$ who work as an assistant, $12 \%$ as an assistant and in a small proportion work in other jobs.

The type of hiring that graduates have in the current job is mainly for a specific time, which occupies $42 \%$; followed by $35 \%$ of graduates hired for an indefinite period; $4 \%$ have a contract for a specific work; $4 \%$ mentioned another type of employment contract but did not specify. Did not answer the question $15 \%$.

Regarding the legal regime of the institution or company where the graduates of the BA in History currently work, it stands out that more than half, $54 \%$, work in private institutions; just over a third, $35 \%$, work in public institutions. The rest of the respondents did not answer the question.

Regarding the time of duration in the current job of the graduates, it stands out that $12 \%$ of these have been between 3 and 7 months, respectively; $8 \%$ mentioned a working seniority of 1,2 and 6 months, respectively; to a lesser extent, with $4 \%$, there are the longest periods ranging from 4, 8 to 66 months, respectively.

Regarding the employment coincidence of the current job carried out by graduates with their undergraduate studies, it should be noted that half consider that they have a total to medium coincidence: $27 \%$ total coincidence and $23 \%$ medium coincidence. Likewise, $27 \%$ indicated that their work has no coincidence and $12 \%$ indicated that it has a low coincidence. The rest did not respond.

Among the main activities carried out in the current job, 15\% mentioned that they are dedicated to sales and customer service, respectively; $8 \%$ indicated that they work in administrative, organizational, coordination and research activities, respectively; the minority, 4\%, mentioned that they are dedicated to planning and training, respectively.

Of the graduates who currently have a job, the following means by which they obtained their job or job stand out: job bank (23\%); relationships made in previous jobs or recommendation of friends / family (15\%), recommendation of friends of the Bachelor's degree (12\%); recommendation from a teacher $(8 \%)$, among others.

Regarding graduates who currently have a job or job, it is worth mentioning that just over a quarter of them, 27\%, mentioned that in addition to their main job they have another job.

Regarding the number of main jobs that graduates have had after completing their undergraduate studies, the following is noteworthy: one third has held two jobs, $15 \%$ one job, $12 \%$ three and four jobs, respectively; to a lesser extent between six and nine jobs.

Comparing the position that graduates had in their job after entering the undergraduate degree with the one they perform in their current job or job, it stands out that little more than a third, 35\%, mentioned that it improved; likewise, 31\% indicated that they are the same; $8 \%$ consider that their current job position worsened with the previous one. The rest of the graduates did not answer the question.

Likewise, in relation to the level of initial income that they had in their job after graduation with their current job, it stands out that it improved for $38 \%$ of graduates, it remained the same for $23 \%$, while it worsened your current job income level for $12 \%$; the rest did not answer the question.

Of the $18 \%$ of graduates who declared that they are currently without work or unemployed, among the most relevant reasons that indicate why they are not working, the following stand out: $33 \%$ mentioned 
that they have not found work but are still looking, $14 \%$ do not have a job because they decided to continue with their studies and in the same proportion argued that for health reasons, respectively; likewise, 33\% mentioned that they do not have a job because they have not looked for it. The rest of the graduates did not answer the question.

\section{Professional performance:}

In this area, the level of satisfaction of the graduates in different aspects of their professional performance in the current job is analyzed:

- Putting knowledge of the degree into practice in your professional performance:

- $41 \%$ feel little satisfied

$-21 \%$ feel satisfied

$-17 \%$ feel very satisfied

$-21 \%$ feel completely satisfied.

- Possibility of making your own ideas in your professional performance:

- $14 \%$ feel little satisfied

$-34 \%$ feel satisfied

- $24 \%$ feel very satisfied

- $28 \%$ feel completely satisfied.

- Professional recognition:

- 34\% feel little satisfied

- 34\% feel satisfied

- $8 \%$ feel very satisfied

- 24\% feel completely satisfied.

- Satisfaction of teamwork:

- $22 \%$ feel little satisfied

- 39\% feel satisfied

- $14 \%$ feel very satisfied

$-25 \%$ feel completely satisfied.

- Respond to work problems in their professional performance:

- $0 \%$ feel little satisfied

- $43 \%$ feel satisfied

- $25 \%$ feel very satisfied

- $32 \%$ feel completely satisfied.

- Satisfaction of the content of the work/activity in their professional performance:

- $8 \%$ feel little satisfied

- $42 \%$ feel satisfied

$-15 \%$ feel very satisfied

- Satisfaction of the work environment:

- $11 \%$ feel little satisfied

$-26 \%$ feel satisfied

- $33 \%$ feel very satisfied 
- 30\% feel completely satisfied.

- Salary satisfaction in current job:

- $42 \%$ feel little satisfied

$-35 \%$ feel satisfied

$-15 \%$ feel very satisfied

- $8 \%$ feel completely satisfied.

- Satisfaction of the hierarchical position reached in current job:

- $16 \%$ feel little satisfied

$-50 \%$ feel satisfied

- $19 \%$ feel very satisfied

- $15 \%$ feel completely satisfied.

- Possibility of responding to problems of social relevance in their professional performance:

$-7 \%$ feel little satisfied

$-41 \%$ feel satisfied

- 33\% feel very satisfied

- $19 \%$ feel completely satisfied.

- Possibility of doing something of benefit to society in your professional performance:

$-8 \%$ feel little satisfied

$-38 \%$ feel satisfied

- $19 \%$ feel very satisfied.

\section{Demands in the daily professional performance of the current job}

In relation to the demands that graduates are required to do in the professional performance of their current job, the following highlights:

- General knowledge of the discipline:

$-23 \%$ very demanding

- $39 \%$ moderate requirement

$-15 \%$ low demand

- $19 \%$ no requirement

- $4 \%$ did not respond.

- Specialized knowledge in professional performance:

$-23 \%$ very demanding

$-50 \%$ moderate requirement

- $12 \%$ low demand

$-15 \%$ no requirement

- $4 \%$ did not respond.

- Knowledge of foreign languages in professional performance:

$-19 \%$ very demanding

$-23 \%$ moderate requirement

- $27 \%$ low demand 
Graduates of the Bachelor of History: Occupational Market, Demands and Level of Satisfaction of Vocational Training

$-27 \%$ no requirement

$-4 \%$ did not respond.

- Skills for handling computer packages in professional performance:

- $19 \%$ very demanding

$-46 \%$ moderate requirement

$-23 \%$ low demand

$-12 \%$ no requirement.

- Logical and analytical reasoning in professional performance:

- $38 \%$ very demanding

- $23 \%$ moderate requirement

- $27 \%$ low demand

$-12 \%$ no requirement.

- Ability to apply knowledge in professional performance:

$-42 \%$ very demanding

- $42 \%$ moderate requirement

- $12 \%$ low demand

- $4 \%$ no requirement.

- Ability to make decisions in professional performance:

- $0 \%$ high demand

- $30 \%$ moderate requirement

- 58\% low demand

$-12 \%$ no requirement.

- Ability to find solutions in professional performance:

- $46 \%$ very demanding

- $42 \%$ moderate requirement

$-12 \%$ low demand

- $0 \%$ no requirement.

- Requirement to search for relevant and updated information on professional performance:

- $46 \%$ very demanding

$-31 \%$ moderate requirement

- $8 \%$ low demand

$-12 \%$ no requirement

- 3\% did not respond.

- Requirement of skills to process and use information in professional performance:

- $38 \%$ very demanding

- $46 \%$ moderate requirement

- $8 \%$ low demand

$-8 \%$ no requirement.

- Requirement of management/coordination skills in professional performance:

- $35 \%$ very demanding

- $42 \%$ moderate requirement 
Graduates of the Bachelor of History: Occupational Market, Demands and Level of Satisfaction of Vocational Training

$-8 \%$ low demand

- $8 \%$ no requirement

- $7 \%$ did not respond.

- Requirement of administrative ability in professional performance:

- $8 \%$ very demanding

- $46 \%$ moderate requirement

- $35 \%$ low demand

- $4 \%$ no requirement

- 7\% did not respond.

- Requirement of willingness to constantly learn in professional performance:

- 54\% very demanding

- $27 \%$ moderate requirement

$-12 \%$ low demand

$-4 \%$ no requirement

- $3 \%$ did not respond.

- Requirement of provision for risk management in professional performance:

- $31 \%$ very demanding

- $35 \%$ moderate requirement

$-19 \%$ low demand

$-12 \%$ no requirement

- $3 \%$ did not respond.

- Requirement of communication skills in professional performance:

$-54 \%$ very demanding

- $31 \%$ moderate requirement

$-12 \%$ low demand

- $3 \%$ no requirement.

- Requirement of punctuality/formality in professional performance:

$-62 \%$ very demanding

- 19\% moderate requirement

$-12 \%$ low demand

- $4 \%$ no requirement

- 3\% did not respond.

- Requirement of good presentation in professional performance:

$-23 \%$ very demanding

- 54\% moderate requirement

$-15 \%$ low demand

- $8 \%$ no requirement.

- Requirement to assume responsibilities in professional performance:

- $62 \%$ very demanding 
Graduates of the Bachelor of History: Occupational Market, Demands and Level of Satisfaction of Vocational Training

$-31 \%$ moderate requirement

- $0 \%$ low requirement

$-7 \%$ no requirement.

- Requirement of creativity in professional performance:

$-39 \%$ very demanding

$-42 \%$ moderate requirement

$-15 \%$ low demand

- $4 \%$ no requirement.

- Requirement of identification with the company / institution in professional performance:

- $46 \%$ very demanding

- $35 \%$ moderate requirement

$-4 \%$ low demand

- $8 \%$ no requirement

$-7 \%$ did not respond.

\section{Opinion on the professional training received}

Higher education develops in a highly demanding context, mainly due to the market, where it is linked to the growth and economic development of countries and their competitiveness, but also substantively fulfills a social function, related to social equity and the decline poverty (Jiménez, 2017).

In this regard, the graduates express their opinion on the occupational and value orientation of their Bachelor of History training and it is characterized as follows:

- Prepared you to choose jobs in different economic sectors:

$-9 \%$ a lot

$-21 \%$ in part

- $34 \%$ little

$-24 \%$ nothing.

$-12 \%$ did not respond.

- Prepared you to work in a specific economic sector:

$-3 \%$ a lot

$-46 \%$ in part

$-27 \%$ little

$-12 \%$ nothing

$-12 \%$ did not respond.

- Prepared you to connect with a particular institution/company:

$-18 \%$ a lot

$-31 \%$ in part

$-21 \%$ little

$-18 \%$ nothing

$-12 \%$ did not respond. 

Vocational Training

- Prepared you to continue training:

$-43 \%$ a lot

$-15 \%$ in part

$-18 \%$ little

$-9 \%$ nothing

- $15 \%$ did not respond.

- Prepared you to think creatively:

$-43 \%$ a lot

$-30 \%$ in part

- $12 \%$ little

- $3 \%$ nothing

- $12 \%$ did not respond.

- Prepared you to develop independently:

- $34 \%$ a lot

$-24 \%$ in part

$-15 \%$ little

- $18 \%$ nothing

- $9 \%$ did not respond.

\section{Relevant aspects to update the study plan studied:}

The opinion of the graduates on the most important aspects that should be updated in the curriculum of the BA in History are the following:

- Theoretical contents:

- $46 \%$ enlarge

$-18 \%$ hold

$-36 \%$ did not respond.

- Methodological contents:

- $67 \%$ enlarge

- $12 \%$ hold

$-3 \%$ reduce

- $18 \%$ did not respond.

- Technical contents:

$-61 \%$ enlarge

$-18 \%$ hold

- $3 \%$ reduce

- $18 \%$ did not respond.

- Professional practices:

$-70 \%$ enlarge

- $15 \%$ hold

- $15 \%$ did not respond. 


\section{Satisfaction with the institution in which you studied the degree and with the career you studied}

According to information provided by the graduates on the assessment of their satisfaction with the institution in which they studied their undergraduate studies, it stands out that the majority, 64\%, mentioned that they would choose UNACH again to carry out their studies; while approximately a quarter of them indicated that they would choose another institution.

Likewise, most of the graduates, $76 \%$, mentioned that they would choose the same career, BA in History, if they were to study at this level again. It should be noted that the minority of graduates (12\%) indicated that they would study another career such as Economics, Architecture, Gastronomy or a teaching career.

\section{CONCLUSION}

Education and training constitute strategic factors for the development and well-being of nations. The new economic scenarios worldwide, González (2000) tells us, require new relationships between education, work and employment; relationships that will be guided by the principle of linking educational institutions and the labor market.

The study of graduates of the degree in History, of the Faculty of Social Sciences, of the UNACH, constitutes a strategy that allows the feedback of the study program and improve the processes of its planning, updating and consolidation. Higher education institutions are currently facing new challenges, among which stand out is the social impact generated by professionals in the labor field. Therefore, it is necessary for institutions to create strategies to analyze this process and identify new training demands that respond to society.

Thus, graduate studies contribute to improving the quality of education, in order to contribute to solving problems. a strategy of continuous and systematic evaluation that serves as the basis for updating the study plans and the innovation of new teaching-learning methods, through the opinion of graduates about the quality of their professional training, the relevance of this in their work performance and suggestions for updating study programs in the face of the demands of the labor market and the social environment they face.

In Mexico, the population with higher education, such as upper level and upper secondary level, only represent a little more than a third of the employed economically active population, and the vast majority is located in the tertiary sector.

In the case of graduates of the BA in History from the Faculty of Social Sciences, UNACH (from the current study plan), the vast majority do not have a degree and although a relevant proportion has current work, less than a quarter of these jobs they occupy are professional level and the contracts are mainly for fixed terms.

Regarding satisfaction in their professional performance, the putting into practice of their undergraduate knowledge, professional recognition and salary received stand out negatively. They consider logical and analytical reasoning in professional performance as fields of greater professional demand, the ability to apply knowledge and find solutions in their professional performance, as well as the search for relevant and updated information, the willingness to constantly learn, skills to communication, punctuality / formality, assuming responsibilities and identification with the company/institution.

The study of graduates of the program in History expresses negative evaluations in the professional training received, especially in the development of their abilities to choose jobs in different economic sectors; however, the positive evaluations regarding the development of capacities to think creatively, develop independently and continue training stand out.

The study of graduates recovers the experiences, evaluations and needs of these professionals in History and expresses the need to strengthen the curriculum in different areas such as the expansion of theoretical, methodological, and technical contents and the implementation of professional practices, relevant factors that will influence in the development of capacities and abilities that will allow them greater opportunities to enter professional-level jobs. 


\section{REFERENCES}

[1] Beck, U. (2008). ¿Qué es la globalización? Falacias del globalismo, respuesta a la globalización. España: Edit. Paidós.

[2] Palacios Gámaz, A. B. (2013). Globalización, desigualdad y población vulnerable: los jóvenes en Latinoamérica y El Caribe. Revista Ethos Venezolana. Volumen 5, No.1, enero-junio de 2013. Pp. 43-55.

[3] Granados Sevilla, A. E. (2013). Introducción. Memoria del Segundo Seminario del Sistema de Información de Estudiantes, Egresados y Empleadores (pp. 13-21). México: UAM.

[4] González García, L. (2000). Nuevas Relaciones entre Educación, Trabajo y Empleo en la Década de los 90. Revista Iberoamericana de Educación. Organización de Estados Iberoamericanos para la Educación, la Ciencia y la Cultura. Recuperado en 30 de mayo del 2020, de: https://www.oei.es/historico/oeivirt/fp/cua d1a03.htm

[5] Instituto Nacional de Estadística y Geografía (2020). Encuesta Nacional de Ocupación y Empleo. https:// www.inegi.org.mx/sistemas/olap/consulta/general_ver4/MDXQueryDatos_Colores.asp?proy=enoe_pe_ed 15_po

[6] Suárez Sánchez, E. (2014). Los estudios de egresados como un elemento de autoevaluación de las IES. Conferencia Magistral presentada en el Foro Seguimiento de Egresados en Educación Superior, UNACH, Tuxtla Gutiérrez, Chiapas.

[7] Rosales Jaramillo, G. L., Rodal Genovez, A.; Chumbi Toledo, V. T. y Buñay Andrade, R. M. (2017). Estudio histórico del seguimiento a graduados en la carrera de Psicología de la Universidad de Cuenca, Ecuador. Revista Cubana de Educación Superior, 36(2), 126-141. Recuperado en 20 de junio de 2018, de http://scielo.sld.cu/scielo.php?script=sci_arttext\&pid=S0257-43142017000200012\&lng=es\&tlng=es.

[8] Organización de Estados Iberoamericanos para la Educación, la Ciencia y la Cultura (2008). Declaración Final de la Conferencia Regional de Educación Superior en América Latina y El Caribe. Conferencial Regional de Educación Superior 2008. Recuperado en 15 de febrero de 2020, de: https://www.oei.es/ historico/salactsi/cres.htm

[9] Aldana de Becerra, G. M.; Morales González, F. A.; Aldana Reyes, J. E.; Sabogal Camargo, F. J. y Ospina Alfonso, Á. R. (2008). Seguimiento a egresados. Su importancia para las instituciones de educación superior. Revista Teoría y Praxis Investigativa, Vol. 3, No.2, septiembre-diciembre, 61-65.

[10] Asociación Nacional de Universidades e Instituciones de Educación Superior (ANUIES) (1998). Esquema básico para estudios de egresados en educación superior. México.

[11] Lopera, C. M. (2005). Los estudios sobre seguimiento a egresados en los procesos de mejoramiento continuo. La actividad universitaria. Seminario para Funcionarios Universitarios y Gubernamentales sobre Seguimiento de Egresados: Monterrey México). En: www. gradua2.org.mx/docs/monterrey/Ponencia_ U_Catolica_de_Col_GRADUA2_Mexico.doc.

[12] Ayala Perdomo, J. C. (2009). Seguimiento laboral de egresados 2008. Licenciatura en Comunicación de la Facultad de Ciencias Políticas y Sociales de la UAEM. Espacios Públicos, 12 (26), 315-328.

[13] Universidad Autónoma del Estado de México (2009). Seguimiento laboral de egresados 2008. Coordinación de Licenciatura en Sociología, Facultad de Ciencias Políticas y Sociales de la UAEM. Revista Espacios Públicos [en línea] 2009, 12 (Diciembre-Sin mes). Disponible en:<http://www.redalyc. org/articulo.oa?id=67612145018>

[14] Guzmán Silva, S.; Febles Álvarez-Icaza, M.; Corredera Marmolejo, A.; Flores Machado, P.; Tuyub España, A. y Rodríguez Reynaga, P. (2008). Estudio de seguimiento de egresados: recomendaciones para su desarrollo. Innovación Educativa, 8 (42), 19-31.

[15] Escalona Ríos, L. y Fernández Cruz, E. (2007). Los estudios de egresados del área bibliotecológica: de la teoría a la práctica. Revista Interamericana de Bibliotecología, Jul.- Dic. 2007, vol. 30, no. 2, 113-135.

[16] Fresán Orozco, M. (1998). Los estudios de egresados. Una estrategia para el autoconocimiento y la mejora de las Instituciones de Educación Superior. En Esquema básico para estudios de egresados en educación superior, ANUIES, México.

[17] Jiménez Moreno, J. A. (2017). La Evaluación de los Egresados de Formación Profesional en México: Reflejo de la Implementación de la Política de Competitividad en la Educación Superior. Education Policy Analysis Archives/Archivos Analíticos de Políticas Educativas, núm. 25, 1-18.

[18] Sandoval Rubio, M. (2009). Seguimiento laboral de egresados 2008. Licenciatura en Ciencias Políticas y Administración Pública de la Facultad de Ciencias Políticas y Sociales de la UAEM. Espacios Públicos, 12 (26), 292-301.

[19] Universidad Autónoma de Chiapas. Secretaría Académica (UNACHa, 2020). Programa Institucional de Egresados. Recuperado en 13 de agosto de 2020, de https://www.egresados.unach.mx/admin/?p=cEgresa dos\&s=consulta 
Graduates of the Bachelor of History: Occupational Market, Demands and Level of Satisfaction of Vocational Training

[20] Universidad Autónoma de Chiapas. Secretaría Académica (UNACHb, 2020). Licenciatura en Historia. Recuperado en 13 de agosto de 2020, de https://secacad.unach.mx/index.php/desarrollo-academico/24ciencias-sociales-y-humanidades/85-historia

Citation: Ana Berónica Palacios Gámaz, et.al. "Graduates of the Bachelor of History: Occupational Market, Demands and Level of Satisfaction of Vocational Training" International Journal of Humanities Social Sciences and Education (IJHSSE), vol 7, no. 11, 2020, pp. 68-83. doi: https://doi.org/10.20431/2349. 0381.0711009 .

Copyright: (C) 2020 Authors. This is an open-access article distributed under the terms of the Creative Commons Attribution License, which permits unrestricted use, distribution, and reproduction in any medium, provided the original author and source are credited. 